\title{
A Low-Protein Diet Restricts Albumin Synthesis in Nephrotic Rats
}

\author{
George A. Kaysen, Hardin Jones, Jr., Victor Martin, and Florence N. Hutchison \\ Renal Biochemistry Laboratory, Division of Nephrology, Department of Medicine, Veterans Administration Medical Center, Martinez, \\ California 94553; and Department of Medicine, University of California Davis School of Medicine, Davis, California 94110
}

\begin{abstract}
High-protein diets increase albumin synthesis in rats with Heymann nephritis but albuminuria increases also, causing serum albumin concentration to be suppressed further than in nephrotic animals eating a low-protein diet. Experiments were designed to determine whether dietary protein augmentation directly stimulates albumin synthesis, or whether instead increased albumin synthesis is triggered by the decrease in serum albumin concentration. Evidence is presented that dietary protein augmentation directly stimulates albumin synthesis, accompanied by a proportional increase in steady-state hepatic albumin mRNA concentration (AlbmRNA) and by an increase in AlbmRNA transcription. When the increased albuminuria resulting from dietary protein augmentation is blunted with enalapril, serum albumin concentration is shown to increase in nephrotic rats. Both albumin synthesis and AlbmRNA increase in these animals despite the greater serum albumin concentration. Albumin synthesis correlates inversely with both serum albumin and serum oncotic pressure in nephrotic rats fed $40 \%$ protein, but does not correlate with serum albumin concentration in nephrotic rats fed 8.5\% protein (LP), even when serum albumin concentration is reduced. Albumin masses are preserved in LP primarily because of reduced albuminuria. Reduced serum oncotic pressure and dietary protein augmentation combine to stimulate albumin synthesis in nephrotic rats at the level of gene transcription.
\end{abstract}

\section{Introduction}

When dietary protein intake is increased from 8.5 to $40 \%$ in nephrotic rats, the rates of both albumin synthesis and urinary albumin excretion increase, but serum albumin concentration tends to decrease. High-protein diets therefore do not lead to correction of the depleted albumin stores in rats with Heymann nephritis. These studies were designed to determine whether the stimulus for increased albumin synthesis was the increase in protein intake or instead whether albumin synthesis is increased in response to a decrement in serum albumin concentration caused by the increased proteinuria. The rate of albumin synthesis depends in part upon adequate calorie and protein intake. Although protein is widely regarded as the most important dietary constituent for the maintenance of a normal serum albumin concentration and a normal rate of albumin synthesis, these parameters also depend on the relative pro-

Address reprint requests to Dr. George A. Kaysen, Medical Service $111 / \mathrm{N}$, Veterans Administration Medical Center, 150 Muir Road, Martinez, CA 94553.

Received for publication 9 June 1988 and in revised form 6 December 1988 .

The Journal of Clinical Investigation, Inc.

Volume 83, May 1989, 1623-1629 portion of protein to nonprotein calories. Maintenance of a diet containing adequate calories but insufficient protein causes reduced albumin synthesis, serum albumin concentration, and total body albumin mass (1-3). One would predict that an ideal diet for patients with the nephrotic syndrome, a disorder that bears much similarity to protein malnutrition, should contain adequate calorie intake, and above all, an adequate or, preferably, a high protein content. Increased dietary protein intake, however, fails to increase either serum albumin concentration or body albumin pools in either patients with the nephrotic syndrome (4-7) or animals with experimentally induced nephrosis (8).

The rates of both albumin synthesis and urinary albumin excretion also increase in nephrotic patients when dietary protein intake is increased, but not in nephrotic patients or animals fed a low-protein diet $(6,8)$, although serum albumin concentration may be quite low. The increase in albumin synthesis in response to augmented dietary protein might be stimulated by the decrease in serum albumin concentration resulting from increasing proteinuria, or instead the increased supply of dietary protein might stimulate albumin synthesis directly.

To distinguish which of these two stimuli was responsible for triggering the increased albumin synthetic rate, we examined the effect of increased dietary protein intake on albumin pools and synthesis rate in rats with passive Heymann nephritis while the increase in albuminuria was controlled by the angiotensin converting enzyme inhibitor, enalapril. This agent was previously found to prevent the increase in urinary albumin excretion resulting from increased dietary protein intake in this model (9). If increased dietary protein is the proximate stimulus for increased albumin synthesis, the combined use of enalapril and a high-protein diet should stimulate albumin synthesis and increase albumin pools in these nephrotic rats. If albumin synthesis increases in response to worsening hypoalbuminemia instead, then prevention of the increment in urinary albumin excretion by angiotensin-converting enzyme inhibitors should remove the stimulus to increased albumin synthesis provided by dietary protein supplementation.

When fasted or protein-malnourished people or animals are fed, the rate of albumin synthesis increases rapidly $(10,11)$ and the increase does not require the synthesis of albumin mRNA, but instead is posttranscriptionally regulated at the level of initiation of protein synthesis (12-14). Albumin synthesis by isolated perfused livers of nephrotic rats is also increased well above that measured in vivo if amino acids are added to the perfusate in generous quantity (15). The rapidity of the response to the addition of amino acids also suggests posttranscriptional regulation. Steady-state hepatic albumin mRNA content is increased in nephrotic rats (16), as is the rate of transcription of albumin mRNA (17), suggesting that regulation of albumin synthesis in nephrosis may occur at the step of mRNA transcription. Hepatic albumin mRNA was mea- 
sured to determine whether increased dietary protein intake would alter steady-state hepatic albumin mRNA content.

\section{Methods}

Nephrotic rats. Male Sprague-Dawley rats weighing $120-150 \mathrm{~g}$ were injected intraperitoneally with sheep FX1A antiserum, (Dr. William Couser, Seattle, WA) and fed Purina diet 5769 (Ralston Purina, Richmond, IN) (8.5\% casein) for a period of $11 \mathrm{~d}$ after injection with antiserum. Thereafter they were studied in one of two experimental protocols.

Protocol 1: nephrotic rats studied at $4 d$ after increased dietary protein intake $(n=26)$. At the end of the initial 11-d period, all animals were placed in metabolic cages. Half were fed Purina diet 5779 (40\% protein), while the other half remained on the low protein diet. The two diets were isocaloric, containing identical amounts of fat and minerals, differing only in the proportion of calories provided either as carbohydrate or as protein. Seven animals in the high protein group (HPE 4), and five animals in the low protein group (LPE 4) had enalapril added to their drinking water $(40 \mathrm{mg} / \mathrm{kg}$ per d) at the same time that dietary protein intake was increased, to blunt the increase in proteinuria anticipated to result from the increased dietary protein intake. The animals switched to $40 \%$ protein that were not treated with enalapril are referred to as HP 4 (six animals), and the animals remaining on $8.5 \%$ protein as LP 4 (eight animals). $4 \mathrm{~d}$ later ( $15 \mathrm{~d}$ after injection with antiserum) albumin distribution and rate of turnover were measured as previously described $(6,8)$. Data from this experimental protocol appear in Table I.

Protocol 2: nephrotic rats studied at $11 \mathrm{~d}$ after increased dietary protein intake $(n=21)$. As in protocol 1 , at the end of the initial $11-\mathrm{d}$ period, all animals were placed in metabolic cages and dietary protein intake was increased to $40 \%$ in 11 animals. Enalapril $(40 \mathrm{mg} / \mathrm{kg}$ per d) was added to the drinking water on day $15,4 \mathrm{~d}$ after the increase in protein intake, in five of the animals eating the high-protein diet (HPE 11), and in five of the animals remaining on low protein (LPE 11). Rats not receiving enalapril are referred to as HP 11 (six animals), and LP 11 (five animals). Albumin turnover and distribution were measured starting $11 \mathrm{~d}$ after the increase in dietary protein intake, $22 \mathrm{~d}$ after injection with antiserum. Data from this experimental protocol appear in Table II.

Protocol 3: nonnephrotic control animals $(n=12) .12$ rats were fed an $8.5 \%$ protein diet for a period of $18 \mathrm{~d}$, after which dietary protein intake was increased to $40 \%$ in six rats (HPC). The remaining animals continued on an $8.5 \%$ protein diet (LPC). Albumin turnover studies were initiated $4 \mathrm{~d}$ after the increase in protein. Because the $t_{1 / 2}$ of ${ }^{125} \mathrm{I}$-albumin is prolonged in nonnephrotic animals $(18,19)$, serum was obtained daily for 8-9 d after injection. Calculations were performed as in the nephrotic animals. Data from this experimental protocol appear in Table III.

Albumin turnover. Albumin turnover and distribution were measured in all animals. Because both serum albumin concentration and urinary excretion rate remained constant during the periods of study, albumin turnover approximates the average rate of albumin synthesis and is henceforth referred to as the rate of albumin synthesis. Rat serum albumin (Sigma Chemical Co., St. Louis, MO) was obtained as Cohn fraction $\mathrm{V}$ and purified by passage over diethylaminoethyl cellulose (microgranular DE 52; Whatman Instruments, Inc., Clifton, NJ) and iodinated with chloramine $T(20)$ as previously described (21) Albumin was assayed in both urine and serum by a sensitive electrodiffusion assay $(6,8,22)$. Serum was noted to be turbid on occasion, because of hyperlipidemia and was therefore centrifuged in a micro air-driven ultracentrifuge (Beckman Instruments, Fullerton, CA) at $120,000 \mathrm{~g}$ for $15 \mathrm{~min}$. Three $10-\mu \mathrm{l}$ aliquots were counted in a gamma counter (Searle Analytics, Des Plaines, IL) for $10 \mathrm{~min}$. The plasma radioactivity disappearance curve was integrated by the method of trapezoids using the log tapazoidal rule (23-25). Plasma volume is calculated by isotope dilution, and plasma albumin mass (PAM) ${ }^{1}$ is the product of serum albumin concentration and plasma volume. Steadystate volume of albumin distribution $\left(V D_{\mathrm{ss}}\right)$ was measured by the method of Benet and Galeazzi (23) and total albumin mass (TAM) is the product of $V D_{\mathrm{ss}}$ and serum albumin concentration (26).

Calculated serum oncotic pressure. Protein concentration was determined on ultracentrifuged serum using the method of Bradford (27). Serum oncotic pressure was calculated using the method of Nitta et al. (27) for determining oncotic pressure of serum with an albumin/ globulin ratio different from 1 .

$R N A$ preparation. At the conclusion of measurement of albumin turnover, animals in protocols 1 and 3 were killed with sodium pentobarbital ( $20 \mathrm{mg} / \mathrm{kg}$ i.p.); the liver was removed and frozen immediately on dry ice. Total RNA was isolated from 200 to $500 \mathrm{mg}$ of frozen liver by homogenization without prior thawing, in $4 \mathrm{M}$ guanidinium thiocyanate, followed by centrifugation through $5.7 \mathrm{M} \mathrm{CsCl}$ (28). Two separate extractions were performed on fragments of tissue from each liver, and the extracted RNA was processed separately. Values presented represent an average of at least two separate determinations.

$20 \mu \mathrm{g}$ of precipitated RNA was electrophoresed on a $1.5 \%$ agaroseformaldehyde gel and then transferred from the agarose gel to nitrocellulose filters by capillary action (29). Degradation was determined in two ways. Gels were permeated with ethydium bromide, visualized with ultraviolet light and photographed. RNA samples failing to show the characteristic bands of ribosomal RNA at $18 \mathrm{~s}$ and $28 \mathrm{~s}$ were not evaluated further.

Because mRNA species might be extracted at a different efficiency than total RNA, each RNA sample was analyzed both for albumin mRNA, and for the mRNA of the constitutively expressed cytoskeletal protein, $\beta$ actin, as an internal standard. $\beta$ actin mRNA is about the same size as that of albumin and the expression of the $\beta$ actin gene should be unaffected by processes that alter expression of the albumin gene. After transfer of RNA, each nitrocellulose filter was analyzed using specific cDNA probes to either albumin or to $\beta$ actin mRNA followed by autoradiography. The presence of degradation was detected by either the absence of the characteristic band at $2 \mathrm{kD}$ found with either of these two RNA species, or the smearing of these bands. If either situation was encountered, the RNA sample was not further analyzed and RNA purification was repeated.

To determine the relative amount of specific mRNAs, quantitative analysis was performed using dot-blot analysis. Serial dilutions of total liver RNA were applied in duplicate to nitrocellulose filters in a minifold (Schleicher \& Schuell, Keene, NH) (30). Duplicate nitrocellulose filters were prepared so that one filter could be hybridized with a cDNA probe prepared against albumin mRNA and the other with a $\beta$ actin probe. Filters were baked under vacuum for $1 \mathrm{~h}$ at $80^{\circ} \mathrm{C}$ and prehybridized at low stringency. Each was then hybridized at $42^{\circ} \mathrm{C}$ with the specific cDNA probes and washed at high stringency. Air-dried filters were autoradiographed overnight at $-70^{\circ} \mathrm{C}$. The dots containing the samples were then cut out and counted in a scintillation counter.

Labeling of cDNA probes. Rat albumin cDNA (pRSA-13) synthesized against purified rat albumin mRNA was obtained as a kind gift from Dr. T. D. Sargent (California Institute of Technology, Pasadena, CA). The cDNA was inserted into the plasmid pBR322 and cloned in Escherichia coli. Plasmid DNA was cleaved with restriction enzyme Pst I (31). The cDNA probe for $\beta$ actin was propagated in the vector/ host system, Okayama Berg: E. coli mm 294CI+. $\beta$ actin cDNA was cleaved from the plasmid DNA with Pst I and Pvu II (32). Both cDNAs were purified by gel electrophoresis and isolated from the agarose gel by electroelution (29). Approximately $60 \mathrm{ng}$ of pRSA-13 and PHFBA$1 \mathrm{cDNA}$ inserts were labeled separately (sp act, $1.0-1.5 \times 10^{9} \mathrm{cpm} / \mu \mathrm{g}$ ) with [ $\left.{ }^{32} \mathrm{P}\right] \mathrm{dCTP}$ by a random primer technique (33) and isolated using Sephadex G-50 columns (Pharmacia Fine Chemicals, Piscataway, NJ) eluted by centrifugation (29).

1. Abbreviations used in this paper: PAM, plasma albumin mass; TAM, total albumin mass; $\mathrm{VD}_{\mathrm{ss}}$, steady-state volume of albumin distribution. 
Northern blot analysis revealed that all hybridization of either albumin mRNA or of $\beta$ actin mRNA was in a single band at $\sim 2 \mathrm{kD}$. There was no evidence of hybridization with any smaller degradation products in any group of animals. Any changes in albumin mRNA hybridization therefore represented a change in full-length albumin mRNA, and not in smaller partially degraded species. The expression of $\beta$ actin did not vary at all within the groups of rats studied, thus validating its use as an internal standard.

Nuclear run-on assays. Nuclear run-on assays were performed to determine whether the increase in steady-state albumin message resulted from an increase in message transcription. Six additional nephrotic rats were fed an $8.5 \%$ protein diet as described in protocol 1 , and protein intake was increased to $40 \%$ in three of the animals $11 \mathrm{~d}$ after injection with FX 1A antiserum. The animals were anesthetized with sodium pentobarbital and hepatic nuclei isolated by the method of Tata (34). Nuclei were incubated for $15 \mathrm{~min}$ at $30^{\circ} \mathrm{C}$ with $166 \mu \mathrm{Ci}$ $\alpha\left[{ }^{32} \mathrm{P}\right] U T P$ to label freshly synthesized RNA. Nuclei were treated with $400 \mu \mathrm{g} / \mathrm{ml}$ proteinase $\mathrm{K}$ and nuclear RNA (35) was extracted with a solution of hot phenol/chloroform/isoamyl alcohol in a ratio of 25:24:1. Nonradioactive cDNAs, one complementary to albumin message, another to the $28 \mathrm{~s}$ ribosomal subunit (propagated in plasmid PBR 322, grown in $E$. coli strain HB 101, obtained as a gift from Dr. Montgomery Bissel) were incubated at $100^{\circ} \mathrm{C}$ in $0.66 \mathrm{M} \mathrm{NaOH}$ and fixed on a nitrocellulose filter in a Hybri-Slot (Bethesda Research Laboratories, Gaithersburg, MD). The 28 s ribosomal RNA was used as the internal control in these experiments, because only very small amounts of $\beta$ actin are produced during these experimental conditions. Labeled RNA $\left(10^{7} \mathrm{cpm} / \mathrm{ml}\right)$ was hybridized to the bound plasmid DNA. The filter was washed at high stringency, treated with $\mathrm{T} 1$ RNAase, RNAase A, and proteinase $K$, patted dry, and autoradiographed. Residual counts were a measure of ${ }^{32} \mathrm{P}$ incorporated into either newly synthesized 28 s ribosomal RNA or into newly synthesized albumin mRNA. Each dot was quantitated by densitometry. The rate of incorporation of ${ }^{32} \mathrm{P}$ into albumin mRNA was determined relative to the rate of incorporation of ${ }^{32} \mathrm{P}$ into $28 \mathrm{~s}$ ribosomal RNA by calculating the ratio of densities of the dots.

Statistics. Plasma and total albumin mass, urinary albumin excretion, and the rate of albumin turnover were all corrected for body weight before analysis. Comparisons were performed using a one-way analysis of variance (36). A value for $P<0.05$ was considered to be statistically significant.

\section{Results}

Rats fed a high-protein diet for $4 \mathrm{~d}$ (Table I, HP 4) had a significantly greater albumin synthesis rate as well as signifcantly more albuminuria than did rats maintained on $8.5 \%$ protein (LP 4). Increased albumin synthesis was accompanied by increased steady-state content of albumin mRNA in the liver. Serum albumin concentration and total and plasma albumin masses were unaffected by dietary protein augmentation alone, despite the increased rate of albumin synthesis. Enalapril blunted the increase in albuminuria in nephrotic rats fed $40 \%$ protein (Table I, HPE 4). Albuminuria was significantly less in this group than in untreated nephrotic rats also fed $40 \%$ protein, but remained significantly greater than in either of the two groups of animals fed $8.5 \%$ protein (LP 4 and LPE 4). Enalapril combined with a high-protein diet caused a significant increase in serum albumin concentration compared to any of the other groups of nephrotic animals studied at $4 \mathrm{~d}$ (Table I). Even though serum albumin concentration was significantly greater in HPE 4, albumin synthesis was significantly greater than in either group fed $8.5 \%$ protein (group LP 4 and LPE 4). It is therefore not possible that hypoalbuminemia alone was the only driving stimulus for increased albumin synthesis.

Albumin synthesis, factored for body weight, correlated with the concentration of albumin mRNA in the liver of nephrotic rats, (albumin synthesis $=7.74 \mathrm{mg} / 100 \mathrm{~g}$ per $\mathrm{h}$ $\times$ albumin $\mathrm{mRNA} / \beta$ actin mRNA $+0.410[r=0.5526, P$ $<0.01$, Fig. $1 A]$ ), or (albumin synthesis $=7.87 \mathrm{mg} / 100 \mathrm{~g}$ per $\mathrm{h}$ $X$ albumin mRNA/total liver RNA [counts bound to $20 \mu \mathrm{g}$ total liver RNA $]+4.235[r=0.5313, P<0.05$, Fig. $1 B])$. The absolute rate of albumin synthesis correlated positively to total liver albumin mRNA if one assumes complete extraction during isolation of albumin mRNA (albumin synthesis $=7.87$ $\mathrm{mg} / \mathrm{h} \times$ total counts hybridized to albumin $\mathrm{mRNA}+8.48$ $\times 10^{-2}[r=0.551, P<0.01$, Fig. $\left.1 C]\right)$. Total counts hybridized to albumin mRNA per liver is the product of counts hybridized to albumin mRNA/micrograms total RNA $\times$ liver weight $\times$ total RNA/liver.

Transcription rate of albumin mRNA relative to that of 28 s ribosomal RNA in isolated hepatic nuclei was significantly greater in nephrotic rats fed a $40 \%$ protein diet $(0.201 \pm 0.025)$ compared with those fed $8.5 \%$ protein, $(0.071 \pm 0.007, P$ $<0.01$ ) (Fig. 2). Because dietary protein augmentation causes increased production of ribosomal RNA $(37,38)$, these findings suggest that the increase in hepatic albumin mRNA content in nephrotic rats fed a high-protein diet results, at least in part, from an enhanced transcription of mRNA from the albumin gene.

After $11 \mathrm{~d}$ of feeding nephrotic animals a high-protein diet (Table II, HP 11), both urinary albumin loss and albumin

Table I. Albumin Metabolism in Nephrotic Rats $4 d$ after Increasing Dietary Protein

\begin{tabular}{|c|c|c|c|c|c|c|c|c|c|}
\hline Group & $n$ & Weight & Serum albumin & UalbV & PAM & TAM & $\begin{array}{l}\text { Albumin } \\
\text { synthesis }\end{array}$ & $\begin{array}{l}\text { Albumin } \\
\text { mRNA }\end{array}$ & $\underset{\beta \text { actin }}{\text { mRNA albumin/ }}$ \\
\hline & & $g$ & $m g / m l$ & $m g / 100 g \cdot h^{-1}$ & \multicolumn{2}{|c|}{$m g / 100 \mathrm{~g}$} & $m g / 100 g \cdot h^{-1}$ & counts $/ 20 \mathrm{ng}$ & \\
\hline HP 4 & 6 & $172.5 \pm 9.6$ & $11.5 \pm 1.0$ & $12.3 \pm 1.2^{* \ddagger}$ & $93 \pm 8.2$ & $230 \pm 48$ & $17.7 \pm 2.31^{\text {*¥ }}$ & $2,041 \pm 389^{* \neq}$ & $22.9 \pm 3.7^{\text {*t }}$ \\
\hline HPE 4 & 7 & $187.4 \pm 14.1$ & $17.8 \pm 2.0^{*}$ & $6.46 \pm 1.22^{* \pm}$ & $125 \pm 15^{*}$ & $317 \pm 37$ & $15.6 \pm 2.45^{\ddagger \S}$ & $1,648 \pm 212^{* \ddagger}$ & $13.8 \pm 2.0^{*}$ \\
\hline LP 4 & 8 & $169.8 \pm 9.04$ & $11.96 \pm 0.96$ & $3.17 \pm 0.25$ & $72.1 \pm 10.8$ & $146 \pm 23$ & $9.64 \pm 0.91$ & $819 \pm 175$ & $8.6 \pm 1.3$ \\
\hline LPE 4 & 5 & $150.5 \pm 5.8$ & $12.7 \pm 2.1$ & $2.98 \pm 0.61$ & $84.1 \pm 11.4$ & $172 \pm 25$ & $8.18 \pm 0.47$ & $728 \pm 84$ & $9.3 \pm 0.8$ \\
\hline
\end{tabular}

Results of experimental protocol $1.11 \mathrm{~d}$ after the intraperitoneal injection of FX $1 \mathrm{~A}$ antiserum, dietary protein intake was increased from 8.5 to $40 \%$ in animals in groups HP 4 and HPE 4 . Animals in groups LP 4 and LPE 4 remained on $8.5 \%$ protein. Enalapril was added to the drinking water in groups HPE 4 and LPE $4.4 \mathrm{~d}$ later ( $15 \mathrm{~d}$ after injection with antiserum) albumin distribution and rate of albumin synthesis was measured over a period of $4 \mathrm{~d}$, after which hepatic albumin mRNA was determined. ${ }^{*} P<0.02$ vs LP. ${ }^{\ddagger} P<0.05$ vs LPE. ${ }^{\S} P<0.05$ vs LP. 

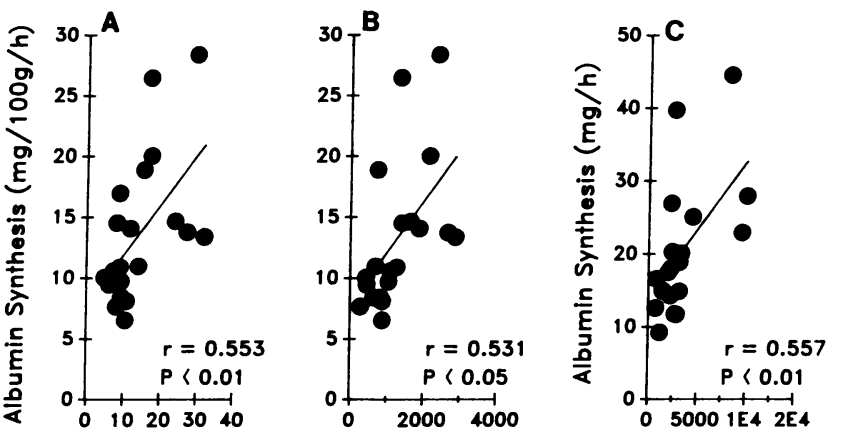

Figure 1. Data obtained from nephrotic rats studied in protocol 1 (HPE 4, HP 4, LPE 4, and LP 4). RNA was not extracted from the livers of three rats and thus no data points are expressed for those animals. $(A)$ Relationship between albumin synthesis rate (milligrams $/ 100$ grams body weight per hour) and the concentration of hepatic albumin mRNA is expressed as the ratio of albumin mRNA $/ \beta$ actin mRNA. The ratio of activities is calculated after hybridization of identical quantities of total liver RNA with radioactive CDNA probes specific to either albumin or $\beta$ actin mRNA. (B) Relationship between albumin synthesis rate (milligrams/ 100 grams body weight per hour) and the concentration of hepatic albumin mRNA expressed as the ratio of albumin mRNA/total liver RNA. $20 \mu \mathrm{g}$ of total RNA were hybridized with a radioactive cDNA probe specific for albumin mRNA. $(C)$ Relationship between albumin synthetic rate (milligrams per hour) and total liver albumin mRNA (counts hybridized to albumin mRNA/liver).

synthesis remained increased and no gradual increase in albumin pools occurred (Fig. 3, Table II). With continued feeding of a low protein diet, urinary albumin excretion decreased $(P$ $<0.005$ in LP 11 vs. LP 4) and serum albumin concentration and albumin pools increased $(P<0.001$ and 0.05 , respectively). Albumin synthesis remained unchanged in nephrotic animals continued on a low-protein diet and studied at $11 \mathrm{~d}$ (LP 11) compared with those studied at $4 \mathrm{~d}$ (LP 4), despite the increase in serum albumin concentration at the later time point.

Serum albumin concentration $(P<0.001)$, PAM $(P$ $<0.01)$, TAM $(P<0.001)$, and albumin synthesis $(P$ $<0.0001)$ were all increased in HPC compared with LPC (Table III). Albumin mRNA/total RNA and albumin mRNA/ $\beta$ actin mRNA were also increased significantly (HPC vs. LPC $P<0.01$ and 0.001 , respectively). Because dot-blot hybridizations with RNA purified from the livers of nephrotic animals or control animals were performed at different times, and the specific radioactivity of the cDNA probes was not the same in each experiment, comparisons between albumin mRNA levels in nephrotic and control animals could not be made.

Albumin synthesis was significantly greater in LPE 11 than in LPC $(P<0.005)$, and tended to be greater in LP 11 . Serum albumin concentration $(P<0.005)$, PAM $(P<0.0001)$, and TAM $(P<0.01)$ were also significantly less in both LP 11 and LPE 11 compared with LPC. Albumin synthesis however, was not greater in either LP 4 or in LPE 4, compared with LPE 11 or LP 11, even though serum albumin concentration, PAM and TAM were much less in both LP 4 and LPE 4. Albumin synthesis therefore can be increased in rats fed $8.5 \%$ protein, but only to a limited extent.

The increase in albumin synthesis in the nephrotic animals fed low protein occurred in response to only a small perturbation in serum albumin concentration (LPE 11 vs. LPC). However, albumin synthesis rate did not increase further in lowprotein-fed nephrotic animals even when serum albumin concentration was very low (LP 4, Fig. 4). In contrast, nephrotic rats fed $40 \%$ protein exhibited no detectable increase in albumin synthesis when serum albumin concentration was only slightly reduced (Table II), but albumin synthesis increased significantly in response to a further decrease in serum albumin concentration (Fig. $3 A$ [Albumin synthesis $=22-(0.38 \times$ serum albumin concentration $) \mathrm{mg} / 100 \mathrm{~g}$ per $\mathrm{h}$, $r=0.5253, P<0.01$ ]) or oncotic pressure (Fig. $3 B$ [Albumin synthesis $=23.9-(0.569 \times$ serum oncotic pressure $) \mathrm{mg} / 100 \mathrm{~g}$ per h, $r=0.46, P<0.05]$ ).

\section{Low Protein-Low Protein}

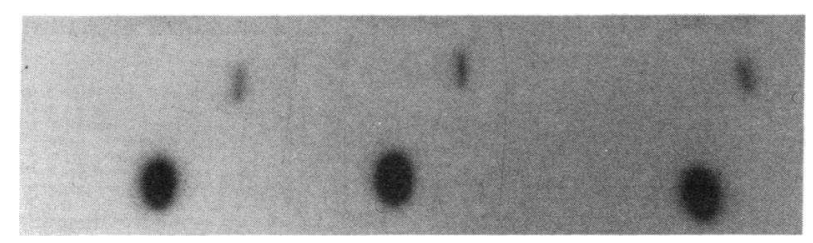

Albumin cDNA

28 s Ribosomal RNA cDNA

\section{Low Protein-High Protein}

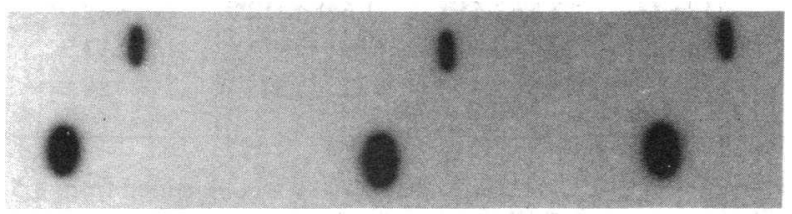

\section{Albumin cDNA}

\section{8 s Ribosomal RNA cDNA}

Figure 2. Autoradiogram of radioactive RNA synthesized by rat liver nuclei after hybridization to nonradioactive cDNA probes directed either against albumin mRNA or against the $28 \mathrm{~s}$ ribosomal subunit. Nuclei were isolated from the livers of nephrotic rats whose diets had been switched from 8.5 to $40 \%$ protein (low protein to high protein), or from the livers of rats that had been continued on an $8.5 \%$ protein diet (low protein to low protein). Nuclei were incubated with $\left[{ }^{32} \mathrm{P}\right]$ UTP and total

RNA was extracted after $30 \mathrm{~min}$ of incubation. The incorporation of ${ }^{32} \mathrm{P}$ into albumin mRNA was measured relative to ${ }^{32} \mathrm{P}$ incorporation into $28 \mathrm{~s}$ ribosomal RNA using densitometry. 
Table II. Albumin Metabolism in Nephrotic Rats 11 d after Increasing Dietary Protein

\begin{tabular}{lccccccc}
\hline Group & $n$ & Weight & Serum albumin & UalbV & PAM & TAM & Albumin synthesis \\
\hline & & $g$ & $m g / m l$ & $m g / 100 g \cdot h^{-1}$ & & $m g / 100 g$ & $m g / 100 g \cdot h^{-1}$ \\
HP 11 & 6 & $178.7 \pm 10.8$ & $13.9 \pm 3^{*}$ & $12.1 \pm 1.4^{*}$ & $87 \pm 10^{*}$ & $196 \pm 25$ & $20.0 \pm 0.71^{*}$ \\
HPE 11 & 5 & $169.8 \pm 4.3$ & $31.6 \pm 1^{*}$ & $1.62 \pm 0.07$ & $172 \pm 9^{*}$ & $296 \pm 18^{*}$ & $7.46 \pm 0.61$ \\
LP 11 & 5 & $165.4 \pm 3.0$ & $24.0 \pm 2.3$ & $1.45 \pm 0.31$ & $116 \pm 12$ & $195 \pm 15$ & $6.84 \pm 1.07$ \\
LPE 11 & 5 & $176.8 \pm 3.6$ & $33.2 \pm 1^{*}$ & $0.47 \pm 0.13$ & $158 \pm 3^{*}$ & $300 \pm 18^{*}$ & $7.47 \pm 0.61$ \\
\hline
\end{tabular}

Results of experimental protocol 2. $11 \mathrm{~d}$ after the intraperitoneal injection of FX $1 \mathrm{~A}$ antiserum, dietary protein intake was increased from 8.5 to $40 \%$ in animals in groups HP 11 and HPE 11. Enalapril was added to the drinking water in groups HPE 11 and LPE $114 \mathrm{~d}$ after the increase in protein intake. Albumin turnover and distribution were measured starting $11 \mathrm{~d}$ after the increase in protein intake, $22 \mathrm{~d}$ after injection with antiserum. ${ }^{*} P<0.05$ vs. LP.

\section{Discussion}

Albumin synthesis rate varied inversely with serum albumin concentration and oncotic pressure in nephrotic rats fed $40 \%$ protein. This increased albumin synthesis was ineffectual in causing an increase in serum albumin concentration when urinary albumin excretion also was increased by the high-protein diet. Nephrotic rats fed a high-protein diet were nevertheless capable of increasing albumin synthesis when hypoalbuminemia occurred. In contrast, although albumin synthesis increased in mildly hypoalbuminemic nephrotic rats eating a low protein diet compared with control animals eating the same diet, additional profound depletion of all albumin pools failed to further augment albumin synthesis (Fig. 4). The limited ability of severely hypoalbuminemic nephrotic rats to in-

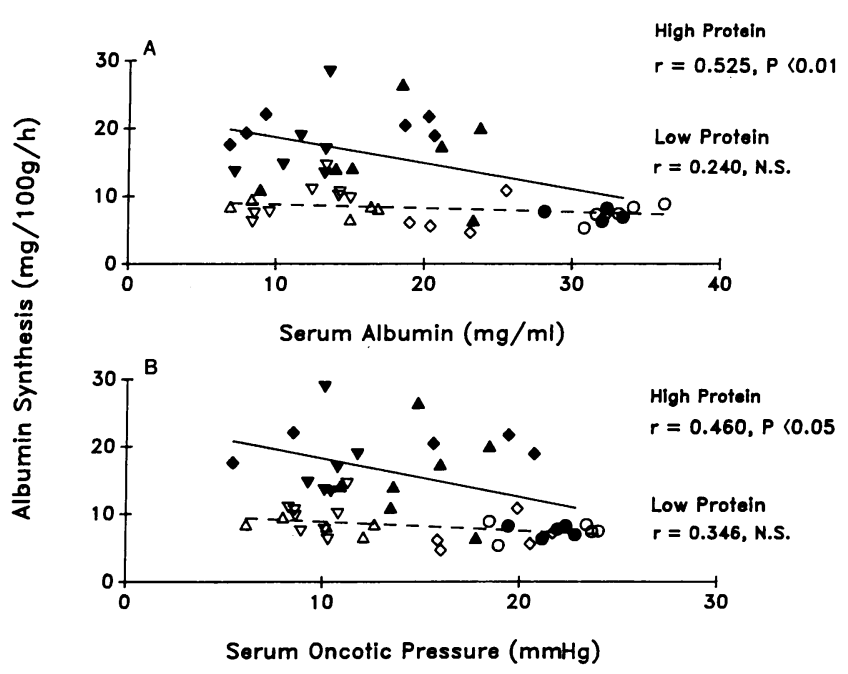

Figure 3. $(A)$ Relationship between the albumin synthetic rate (milligrams/100 grams body weight per hour) and serum albumin concentration in nephrotic rats either maintained on a diet containing $8.5 \%$ protein (low protein); open symbols, broken line), or switched to a $40 \%$ protein diet (high protein; closed symbols, solid line). $\bullet$, HPE

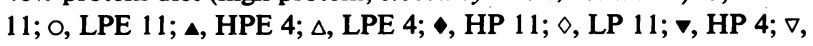
LP 4. (B) Relationship between the albumin synthetic rate (milligrams/100 grams body weight per hour) and calculated serum oncotic pressure in nephrotic rats either maintained on a diet containing $8.5 \%$ protein (low protein), or switched to a $40 \%$ protein diet (high protein). Symbol notation is as in $A$. crease albumin synthetic rate when fed a low-protein diet suggests that the response to reduced serum albumin concentration is blunted by the low availability of protein in this diet. The observation that albumin synthesis was greater in HPE 4 than in LP 4 and LPE 4, even though all albumin pools were greater in HPE 4, indicates that the enhanced rate of albumin synthesis was a direct result of dietary protein supplementation and not driven entirely by a decrement in serum albumin concentration. Indeed, the higher rate of albumin synthesis was directly responsible for the increase in albumin pools in HPE 4, because urinary albumin excretion was significantly greater than in either LP 4 or LPE 4.

Although serum albumin concentration, PAM and TAM are decreased only slightly in LPC compared with HPC, both albumin mass and albumin synthetic rate are dependent upon protein intake even in normal animals. These observations strongly support a hypothesis that augmentation of dietary protein stimulates albumin synthesis directly.

Increased dietary protein intake might augment albumin synthetic rate simply by providing increased substrate (amino acids) necessary for protein synthesis. The increase in the hepatic content of albumin mRNA suggests that the effect of dietary protein augmentation on albumin synthesis is more complex. Albumin synthesis is regulated, at least in part, by regulation of the steady-state content of albumin mRNA in the liver. Whereas the steady-state concentration of a specific mRNA may be increased either by an increase in the rate of gene transcription or by stabilization of mRNA, our data are consistent with the hypothesis that dietary protein augmentation increases hepatic albumin mRNA in nephrotic rats by increasing the rate of transcription of mRNA from the albu-

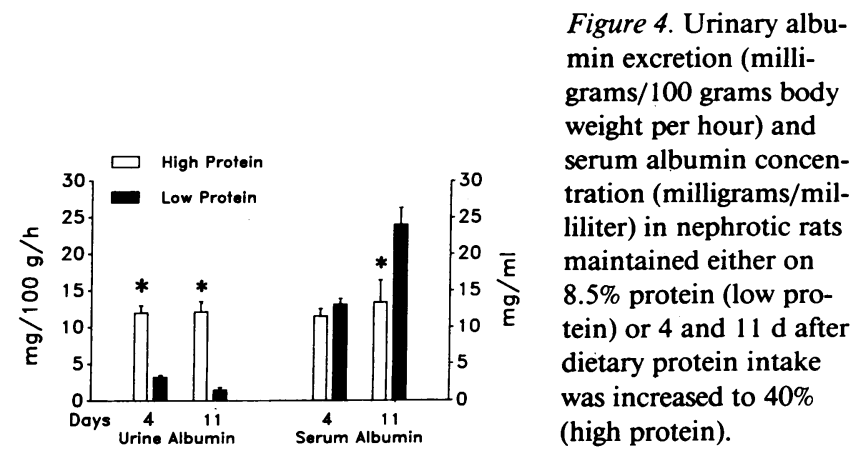


Table III. Albumin Metabolism in Nonnephrotic Rats after Increasing Dietary Protein

\begin{tabular}{ccccccccc}
\hline Group & $n$ & Weight & $\begin{array}{c}\text { Serum } \\
\text { albumin }\end{array}$ & PAM & TAM & $\begin{array}{c}\text { Albumin } \\
\text { synthesis }\end{array}$ & $\begin{array}{c}\text { Albumin } \\
\text { mRNA }\end{array}$ & $\begin{array}{c}\text { mRNA albumin/ } \\
\beta \text { actin }\end{array}$ \\
\hline & & $g$ & $m g / m l$ & \multicolumn{2}{c}{$m g / 100 g$} & $m g / 100 g \cdot h^{-1}$ & counts/20 ng \\
HPC & 6 & $220.5 \pm 4.1$ & $42.7 \pm 0.6^{*}$ & $194 \pm 4.8^{\ddagger}$ & $489 \pm 20^{*}$ & $7.39 \pm 0.14^{*}$ & $5,622 \pm 428^{\ddagger}$ & $5.36 \pm 0.48^{*}$ \\
LPC & 6 & $223.3 \pm 4.8$ & $37.9 \pm 0.7$ & $166 \pm 6.3$ & $441 \pm 31$ & $5.05 \pm 0.11$ & $2,213 \pm 343$ & $2.74 \pm 0.34$ \\
\end{tabular}

Results of studies on nonnephrotic control animals (experimental protocol 3). After $18 \mathrm{~d}$ of consumption of an $8.5 \%$ protein diet, dietary protein intake was increased to $40 \%$ in HPC and retained at $8.5 \%$ in LPC. Albumin distribution and the rate of albumin synthesis were measured between 4 and $13 \mathrm{~d}$ after the increase in protein intake, after which hepatic albumin mRNA was measured in each animal. ${ }^{*} P<0.001$ vs. LP. ${ }^{\ddagger} P<0.01$ vs. LP.

min gene. A similar mechanism appears to be responsible for the increase in albumin synthesis that occurs in nonnephrotic rats as albumin mRNA is increased in control animals as well.

Two important factors regulating albumin synthetic rate are nutritional status $(39,40)$ and oncotic pressure $(41-44)$. Katz et al. (15) found that albumin synthetic rate was increased only twofold in the nephrotic rat in vivo, but could be increased in the livers isolated from these animals to five times the basal rate if amino acids were provided in the perfusate. Albumin synthesis was inversely proportional to the oncotic pressure of the perfusing solution in the isolated livers $(15,45)$. It thus was possible that reduced serum oncotic pressure alone provided only a partial impetus to albumin synthesis in nephrotic rats, and that reduced oncotic pressure and excess amino acid supply combined to further amplify albumin synthetic response to hypoalbuminemia. Even the combination of reduced serum oncotic pressure and a $40 \%$ protein diet may not be sufficient to maximally stimulate albumin synthesis in the nephrotic rat. The rate of albumin synthesis in HPE 11 was no greater than in HPC, although serum albumin concentration was significantly less in the nephrotic animals. Factors other than dietary protein intake and serum oncotic pressure, not identified in these experiments, may limit albumin synthetic rate in the nephrotic syndrome.

Albumin pools and serum albumin concentration increase during consumption of a low-protein diet only because the reduction in urinary albumin excretion is more biologically significant than is the reduction in albumin synthesis. Increased albumin synthesis that occurs in high-protein-fed nephrotic rats is ineffectual in causing an increase in either serum albumin concentration or albumin mass if urinary albumin excretion is also increased as a result of consumption of the high-protein diet. If this increase in albuminuria can be mitigated, albumin stores are increased in the nephrotic rat by dietary protein supplementation.

\section{Acknowledgments}

We thank Dr. Steven Embury and Dr. Montgomery Bissel for their generous help.

This work was supported in part by the research service of the United States Veterans Administration.

\section{References}

1. Smith, J. E., and P. G. Lunn. 1984. Albumin-synthesizing capacity of hepatocytes isolated from rats fed diets differing in protein and energy content. Ann. Nutr. \& Metab. 28:281-287.
2. Lunn, P. G., and S. Austin. 1983. Excess energy intake promotes the development of hypoalbuminemia in rats fed on low-protein diets. Br. J. Nutr. 49:9-16.

3. Coward, W. A., and M. B. Sawyer. 1977. Whole-body albumin mass and distribution in rats fed on low-protein diets. Br. J. Nutr. 37:127-134.

4. Farr, L. E. 1938. The assimilation of protein by young children with the nephrotic syndrome. Am. J. Med. Sci. 195:70-83.

5. Keutmann, E. H., and S. H. Bassett. 1935. Dietary protein in hemorrhagic Bright's disease. II. The effect of diet on serum proteins, proteinuria and tissue proteins. J. Clin. Invest. 14:871-888.

6. Kaysen, G. A., J. Gambertoglio, I. Jiminez, H. Jones, and F. N. Hutchison. 1986. Effect of dietary protein intake on albumin homeostasis in nephrotic patients. Kidney Int. 29:572-577.

7. Rosenberg, M. E., J. E. Swanson, B. L. Thomas, and T. H. Hostetter. 1987. Glomerular and hormonal responses to dietary protein intake in human renal disease. Am. J. Physiol. 253:(Renal Fluid Electrolyte Physiol. 22):F1083-F1090.

8. Kaysen, G. A., W. G. Kirkpatrick, and W. G. Couser. 1984. Albumin homeostasis in the nephrotic rat: nutritional considerations. Am. J. Physiol. 247: (Renal Fluid Electrolyte Physiol. 16):F192-F202.

9. Hutchison, F. N., M. Schambelan, and G. A. Kaysen. 1987. Modulation of albuminuria by dietary protein and converting enzyme inhibition. Am. J. Physiol. 253: (Renal Fluid Electrolyte Physiol. 22):F719-F725.

10. James, W. P. T., P. M. Sander, and J. C. Waterlow. 1976. Nutritional aspects of plasma protein metabolism: the relevance of protein turnover rates during malnutrition and its remission in man. In Plasma Protein Turnover. R. Bianchi, G. Mariani, and A. S. McFarlane, editors. University Park Press, Baltimore, MD. 251-263.

11. Kirsch, R. E., L. E. C. Frith, and S. J. Saunders. 1976. Stimulation of albumin synthesis by keto analogues of amino acids. Biochim. Biophys. Acta. 442:437-441.

12. Morgan, E. H., and T. Peters, Jr. 1971. The biosynthesis of rat serum albumin. J. Biol. Chem. 246:3500-3507.

13. Yap, S. H., R. K. Strair, and D. A. Shafritz. 1978. Identification of albumin mRNP's in the cytosol of fasting rat liver and influence of tryptophan or a mixture of amino acids. Biochem. Biophys. Res. Commun. 83:427-433.

14. Princen, J. M. G., G. P. B. M. Backx, and S. H. Yap. 1983. Restoration effects of glucose refeeding on reduced synthesis of albu$\mathrm{min}$ and total protein and on disaggregated polyribosomes in liver of starved rats: evidence of a post-transcriptional control mechanism. Ann. Nutr. \& Metab. 27:182-193.

15. Katz, J., G. Bonorris, S. Okuyama, and A. L. Sellers. 1967. Albumin synthesis in perfused liver of normal and nephrotic rats. $\mathrm{Am}$. J. Physiol: 212:1255-1260.

16. Zähringer, J., B. S. Baliga, and H. N. Munro. 1976. Increased levels of microsomal albumin mRNA in the liver of nephrotic rats. FEBS (Fed. Eur. Biochem. Soc.) Lett. 62:322-325.

17. Yamauchi, A., E. Imai, T. Noguchi, T. Tanaka, S. Yamamoto, H. Mikami, Y. Fukuhara, M. Fujii, Y. Orita, and T. Kamada. 1988. 
Albumin gene transcription is enhanced in liver of nephrotic rats. $\mathrm{Am}$ J. Physiol. 254:(Endocrinol. Metab. 17):E676-E679.

18. Sellers, A. L., J. Katz, G. Bonorris, and S. Okyyama. 1966 Determination of extravascular albumin in the rat. J. Lab. Clin. Med. 68:177-185.

19. Sellers, A. L., J. Katz, and G. Bonorris. 1968. Albumin distribution in the nephrotic rat. J. Lab. Clin. Med. 71:511-516.

20. Roberts, R. C., C. O. Sonnentag, and J. H. Frisbie. 1972. Rapid preparation of autologous radioiodinated fibrinogen. J. Nucl. Med. 13:834-846.

21. Kaysen, G. A., and J. B. Watson. 1982. Mechanism of hypoalbuminemia in the $7 / 8$ nephrectomized rat with chronic renal failure. Am. J. Physiol. 243:(Renal Fluid Electrolyte Physiol. 12):F372-F378.

22. Laurell, C. B. 1972. Electroimmunoassay. Scand. J. Clin. Lab. Invest. 29(Suppl. 124):21-23.

23. Benet, L. Z., and R. L. Galeazzi. 1979. Noncompartmental determination of the steady-state volume of distribution. J. Pharmacol. Sci. 68:1071-1074.

24. Riegelman, S., and P. Collier. 1980. The application of statistical moment theory to the evaluation of in vivo dissolution time and adsorption time. J. Pharmacokinet. Biopharm. 8:509-534.

25. Kaysen, G. A., and P. Y. Schoenfeld. 1984. Albumin homeostasis in patients undergoing continuous ambulatory peritoneal dialysis. Kidney Int. 25:107-114.

26. Bradford, M. M. 1976. A rapid and sensitive method for the quantitation of microgram quantities of protein utilizing the principle of protein dye binding. Anal. Biochem. 72:248-254.

27. Nitta, A., T. Ohnuki, O. Kazuhiro, T. Nakada, and N. C. Staub. 1976. The corrected protein equation to estimate plasma colloid osmotic pressure and its development on a nomogram. Tohoku J. Exp. Med. 135:43-49.

28. Chirgwin, J. M., A. E. Przybyla, R. J. MacDonald, and W. J. Rutter. 1979. Isolation of biologically active ribonucleic acid from sources enriched in ribonuclease. Biochemistry. 18:5294-5299.

29. Maniatis, T., E. F. Fritsch, and J. Sambrook. 1982. Molecular Cloning: A Laboratory Manual. Cold Spring Harbor Laboratory, Cold Spring Harbor, New York. 464-467.

30. White, B. A., and F. C. Bancroft. 1982. Cytoplasmic dot hybridization. J. Biol. Chem. 257:8569-8572.

31. Sargent, T. D., M. Yang, and J. Bonner. 1981. Nucleotide sequence of cloned rat serum albumin messenger RNA. Proc. Natl. Acad. Sci. USA. 78:234-246.
32. Okayama, H., and P. Berg. 1983. A cDNA cloning vector that permits expression of cDNA inserts in mammalian cells. Mol. Cell. Biol. 3:280-289.

33. Feinberg, A. P., and B. Vogelstein. 1983. A technique for radiolabeling DNA restriction endonuclease fragments to high specific activity. Anal. Biochem. 132:6-13.

34. Tata, J. R. 1974. Isolation of nuclei from liver and other tissues. Methods Enzymol. 31:253-262.

35. Soeiro, R., and J. E. Darnell, Jr. 1969. Competition hybridization by presaturation of HeLa cell DNA. J. Mol. Biol. 44:551-562.

36. Matthews, D. E., and W. Farewell. 1985. Using and Understanding Medical Statistics. S. Karger, Basel/New York. 132-138.

37. Hendersen, A. R. 1970. The effect of feeding with a tryptophan-free amino acid mixture on rat liver magnesium ion-activated deoxyribonucleic acid-dependent ribonucleic acid polymerase. Biochem. J. 120:205-214.

38. Vesely, J., and A. Cihak. 1970. Enhanced DNA-dependent RNA polymerase and RNA synthesis in rat liver nuclei after administration of L-tryptophan. Biochim. Biophys. Acta. 204:614-616.

39. Kirsch, R. E., L. Frith, E. Black, and R. Hoffenberg. 1968. Regulation of albumin synthesis and catabolism by alteration of dietary protein. Nature (Lond.). 217:578-579.

40. Kirsch, R. E., S. J. Saunders, L. Frith, S. Wight, L. Kelman, and J. F. Brock. 1969. Plasma amino acid concentration and the regulation of albumin synthesis. Am. J. Clin. Nutr. 22:1559-1562.

41. Rothschild, M. A., M. Oratz, E. C. Franklin, and S. S. Schreiber. 1967. The effect of hypergamma-globulinemia on albumin metabolism in hyperimmunized rabbits studied with albumin $\mathrm{I}^{131} . J$. Clin. Invest. 41:1564-1571.

42. Dich, J., S. E. Hansen, and H. I. D. Thieden. 1973. Effect of albumin concentration and colloid osmotic pressure on albumin synthesis in the perfused liver. Am. J. Physiol. 216:1127-1130.

43. Huberman, A. 1973. The in vitro effect of colloid osmotic pressure on albumin biosynthesis in normal rat liver. Rev. Invest. Clin. 25:321-326.

44. Oratz, M., M. A. Rothschild, and S. S. Schreiber. 1970. Effect of dextran infusions on protein synthesis by hepatic microsomes. Am. J. Physiol. 218:1108-1112.

45. Oratz, M. 1976. Oncotic pressure and albumin synthesis. In Plasma Protein Turnover. R. Bianchi, G. Mariani, and A. S. McFarlane, editors. University Park Press, Baltimore, MD. 223-237. 